\title{
A Mixed Method Study of Teachers' Attitudes towards Computer Pronunciation Software in Teaching English Pronunciation
}

\author{
Abbas Pourhosein Gilakjani \\ English Translation Department, Lahijan Branch, Islamic Azad University, Lahijan, \\ Iran,abbas.pourhossein@yahoo.com \\ Reihaneh Sheikhy \\ Department of English Language, Lahijan Branch, Islamic Azad University, Lahijan, \\ Iran, reihaneh.sheikhy322@gmail.com

\section{Iraj Montashery} \\ English Translation Department, Lahijan Branch, Islamic Azad University, Lahijan, \\ Iran,iraj.montashery@gmail.com

\section{Mitra Alizadeh} \\ English Translation Department, Lahijan Branch, Islamic Azad University, Lahijan, \\ Iran, alizadehmitra4@gmail.com
}

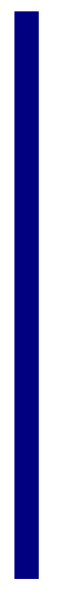

\begin{abstract}
This mixed study investigates the attitudes teachers in English institutes have about computer pronunciation software in teaching English pronunciation. Pronunciation Power 2 was used for this purpose. First, a survey was used as the quantitative method. 55 teachers from 5 English institutes took part in this research and these institutes were randomly selected out of 10 institutes in Guilan, Iran. A questionnaire consisting of 21 items was used as the instrument of quantitative method. To analyze quantitative data, descriptive statistics methods like frequency, percentage, and mean were used. The findings of quantitative method indicated that teachers' attitudes towards Pronunciation Power 2 are highly positive and they realized it as a useful means of teaching pronunciation. The findings also revealed that teachers should be trained in this software so that they use it appropriately and effectively. Second, an interview was used as the qualitative method. Five teachers were selected voluntarily from five institutes. Semi-structured interview questions were used as the instrument of qualitative method. The qualitative data analysis was done through examining, and organizing data, coding, and identifying themes.
\end{abstract}

Keywords: teachers, attitudes, computer, teaching, pronunciation, EFL

Citation: Gilakjani, A. P., Sheikhy, R., Montashery, I., \& Alizadeh, M. (2019). A Mixed Method Study of Teachers' Attitudes towards Computer Pronunciation Software in Teaching English Pronunciation. International Journal of Instruction, 12(1), 821-840. https://doi.org/10.29333/iji.2019.12153a 


\section{INTRODUCTION}

Pronunciation is considered as one of the most difficult skills in English language teaching and learning that requires a great deal of work and effort (Haghighi \& Rahimy, 2017; Sadeghi \& Mashhadi Heidar, 2016). Pronunciation has always been ignored and no serious attempt has been made to understand the significance of this language skill (Farhat \& Dzakiria, 2017). According to Hayati (2010), Iranian teachers do not usually pay attention to pronunciation and believe that they lack the time for teaching it and overcrowded classes do not allow them to teach it effectively (cited in Pourhosein Gilakjani \& Sabouri, 2014a). According to Celce-Murcia, Brinton, and Goodwin (2004), Kelly (2000), and Král'ová and Metruk (2012), good pronunciation is regarded as a sign of higher social positions and quality education. Poor pronunciation negatively influences comprehensibility of communication and distracts listeners. As a result, knowledge of correct pronunciation is considered as a key component of communicative competence. One serious problem pertinent to pronunciation instruction is related to teachers' attitudes. A lot of them do not feel confident about their own pronunciation and try to stop teaching it in their classes. Pronunciation instruction is a somehow neglected linguistic system in the foreign language education due to teachers' attitudes, inadequate teacher-training, and lack of appropriate materials in textbooks (cited in Pokrivčáková et al., 2015). In this situation, the use of pronunciation-training computer programs seems to be the useful and effective remedy.

The impact of using computer on education has been examined by many researchers in various studies. These researches have indicated that the application of computer has a strong effect on education and it leads to the development of teaching methods and learners' knowledge (Aziz Mohammadi \& Samadi, 2014). Lam and Lawrence (2002) supported the idea that computer helps learners control their learning process and provides them further information over which their teachers cannot control them. In spite of the rapid growth of computer technologies and their positive impacts on both teaching and learning pronunciation, a lot of Iranian teachers do not use them for teaching pronunciation (Pirasteh, 2014) and there are a lot of differences between the degree of using these technologies and what is expected to use. This can be observed in research projects conducted on the usefulness of technologies in teaching pronunciation in Iranian classes (Gorjian, Hayati, \& Pourkhoni, 2013; Mehrpour et al., 2016). It is recommended that Iranian schools, institutes, and universities use these technologies and incorporate them in their classes.

Hayati (2010) said that one of the best means of improving and solving pronunciation teaching and learning is to use computer technology. Computer technology provides new possibilities for teaching pronunciation, creates a successful language environment for both teachers and learners, provides new opportunities for teachers and learners to engage in active communication that facilitates the process of teaching and learning English pronunciation (cited in Pourhosein Gilakjani \& Sabouri, 2014a). Pourhosein Gilakjani and Sabouri (2014a) expressed that the practical use of computer relies on many factors like funding, lesson plans, and decisions about hardware and software and whether these factors lead to the learning outcomes or not are determined by teachers 
whose attitudes influence the decisions they make about the way of applying technologies.

Pettenai, Giuli, and Khaled (2001) stated that since teachers are the key persons who encourage any innovation in education, it is significant to help them integrate computer technology successfully into their teaching. According to Jafari, Dabaghi, and Vahid Dastjerdi (2015), teachers are regarded as the key factors in changes as their attitudes may support or stop using computer technologies. However, some Iranian teachers do not have good attitudes towards applying computer technology in teaching pronunciation. Although they use computer in their teaching, but due to the lack of good attitudes, they are not able to get the desirable results towards using it in their classrooms. It is especially important to realize teachers' attitudes towards using computer pronunciation software (Pronunciation Power 2, PP2) in teaching pronunciation, due to the fact that they have a key role in education. Therefore, the researchers investigated teachers' attitudes towards Pronunciation Power 2 (PP2) in teaching pronunciation.

\section{REVIEW OF THE LITERATURE}

Computer-assisted pronunciation teaching (CAPT) systems use methods like speech recognition, speaker normalization, and signal parameter that give visible comparisons between learners' attempts and the model. Through other software, learners can compare and receive immediate feedback on their pronunciation by visual diagrams. CAPT has a lot of pronunciation activities, different exercises that helps teachers and learners to develop their pronunciation teaching and learning (Ong'onda \& Muindi, 2016). Computer assisted software provides a native-like, real language learning environment and it provides immediate feedback on learners' performance (Neri et al., 2002). Hirata (2004) found that CAPT was very effective in improving L2 learners' ability to produce and perceive various aspects of pronunciation. In the same way, Raux and Kawahara (2002) revealed that computerized pronunciation instruction is effective because it provides meaningful feedback to learners on their strengths and weaknesses. Furthermore, Stibbard (1996) found that computer technological advances help learners develop their skills in learning different aspects of language like pronunciation.

One of the factors that influences the effective usage of computers is teachers' attitudes towards computers and these attitudes impact on teachers' computer use (Teo, 2006). According to Huang and Liaw (2005), the successful application of computer technology hinges on teachers' positive attitudes towards it. Wong et al. (2005) investigated the utilization of Internet among teachers. The findings of this study indicated that teachers' use of Internet was affected by their confidence, attitudes, and its understanding. Yildirim (2000) noticed that teachers who frequently use computers have a tendency to develop positive attitudes towards them in their teaching activities. Gobbo and Girardi (2001) asserted that there is a positive relationship between computer training and teachers' attitudes. Training impacts the ways in which teachers embrace computer in their classes. Gobbo and Girardi (2001) examined teachers' teaching styles and computer integration. The findings indicated that both theories of teaching and competence with computer have a key role in implementing computer in 
teachers' classes. Teachers should have enough opportunity to be familiar with new technologies.

Mcalister et al. (2005) realized that teachers' attitudes towards computer were positive, although a lot of them did not have sufficient experience with computer. They emphasized that teachers should be trained in Information Technology (IT) and they should be valued as a role model for their learners. Gulbahar (2008) found that lack of training and insufficient technological infrastructures had an effect on the successful use of computer among teachers. Egbert, Paulis, and Nakamichi (2002) carried out a study on teachers' views towards computer. The findings of their study represented that lack of time, support, and resources prevented teachers from using Computer-Assisted Language Learning (CALL). In addition, Jones (2002) said that teachers should know the correct use of computer and he emphasized the significance of training for teachers. Software availability and teacher readiness to use it have positive impacts on teachers' attitudes towards adopting technology in the classroom. Furthermore, Kersaint (2003) indicated that teachers who have good attitudes towards computer feel more comfortable and incorporate it into their teaching.

Teachers' role is related to their interest in computer and their attitudes towards computer (Rohaan, Taconis, \& Jochems, 2010). Cavas and Kesercioğlu (2003) investigated teachers' attitudes towards CALL. The findings demonstrated that many teachers had positive attitudes towards CALL and there was not gender difference between teachers' attitudes towards computer-assisted learning. Ocak and Akdemir (2008) stated that teachers' computer literacy is pertinent to the use of computer. Teachers' computer literacy helps them to integrate computer in their instruction. Teachers' attitudes towards computer are relevant to their computer competence. Berner (2003) declared that teachers' computer competence is closely related to their computer attitudes. Al-Oteawi (2002) found that most teachers who had negative or neutral attitudes towards Information and Communication Technology (ICT) in their classes lacked skill about computers.

Use of computer is influenced by previous computer experience. Negative attitude towards using computer decreases confidence and increases worry. The lack of computer technology knowledge leads to anxiety and lack of confidence; as a result, teachers may feel uncomfortable with technology (Chen, 2008; Finley \& Hartman, 2004). Some researches have been conducted on applying computer in English as a Foreign Language (EFL) programs in Iran. Tahriri, Azim Dokht, and Derakhshan (2013) performed a research on Iranian teachers' attitudes towards computer. The findings indicated that teachers have positive attitudes towards computer in their teaching. In addition, Mollaei and Riasati (2013) performed a study about Iranian teachers' attitudes towards applying computer. The results represented that Iranian teachers have positive attitudes toward using computer in their instruction. Finally, Sadeghi, Rahmany, and Doosti (2014) conducted a study and the findings showed that Iranian teachers who worked with computers more than other teachers had positive attitudes towards applying them in EFL classrooms. 


\section{Features of Pronunciation Power Software}

Pronunciation Power Software has been developed by English Computerized Learning Inc. It consists of two software: Pronunciation Power 1 (PP1) and Pronunciation Power 2 (PP2). Pronunciation Power 1 has 7000 practice words and sentences, 100 hours of training, 2000 photos and graphics, animated lessons, 1020 listening exercises, hours of exercises for practicing stress, timing, articulation, intonation, and rhythm and four exciting new games (Pronunciation Power, 2000). Pronunciation Power 2 has all the features of PP1 plus 52 sounds that are necessary for speaking skill, comparing your sound to the sound of teachers, seeing how sounds are made by moving the animated side view of the mouth and the tongue, testing your listening skill with 650 different sentence exercises, practicing pronunciation through interactive and exciting exercises including 780 sample words and 1040 different sentences (Pronunciation Power, 2000).

\section{Application of Pronunciation Power 2 (PP2)}

Fluent speaking skills can be developed through using Pronunciation Power 2 (PP2). Pronunciation Power 2 provides more advanced practice with full sentence intonation and more advanced vocabulary practice. Pronunciation Power 2 completes what learners are learning in class and help them increase their pronunciation learning. Teachers can use this program in their classrooms to complete their pronunciation instruction. While learners are progressing on their own, this permits teachers to work with each student separately (Pronunciation Power, 2000). With the variety of materials and activities it provides, Pronunciation Power 2 is appropriate for the teaching and learning of pronunciation under different conditions. It has a lot of rich skill components involving different activities for improving and teaching listening, speaking, and specifically English pronunciation (Pronunciation Power, 2000).

\section{Use of Different Kinds of Pronunciation Software for Teaching Pronunciation}

There are other software for teaching pronunciation like Connected Speech, Streaming Speech, Electronic Dictionaries, and Accent Master software. The first software is Connected Speech. The purpose of this software is to help learners connect the speech production to the actual speaking skill, and produce natural English (Protea Textware, 2007). The second one is Streaming Speech software that involves aspects of British and American pronunciation, ranging from intermediate to advanced courses (Cauldwell, 2002). The third one is Electronic dictionaries software that promotes learner autonomy in the learning of pronunciation. Through this software, users listen to the pronunciation of words in isolation and in connected speech, record their voice and listen to their own production, and compare it with the native-like pronunciation (Jenkins, 2004). The fourth one is Accent Master software that has special features like videos of an authentic American speaker producing each sound, a visual sound comparison which enables learners to see their voice in comparison to those of the model speakers, video instructions for advanced lessons, and a 52 American English phoneme. The users can hear American English speakers pronounce every sound, word, and sentence. This software involves different lessons which work on both segmentals and suprasegmentals. In addition, it permits learners to record their voice and compare it to that of 
a native speaker. Furthermore, it provides learners with visual aids like showing articulatory organs while pronouncing sounds and helpful video instructions (Bo \& Bo, 2005).

\section{METHOD}

\section{Research Design}

The design of this study was two-fold: on the one hand, a survey was used as the quantitative method design of this research. In order to evaluate teachers' attitudes towards using computer in pronunciation instruction, a questionnaire consisting of 21 items was used as the instrument of quantitative method. Questionnaires are considered as one of the good ways of gathering data on attitudes from a large group of participants. The reason behind this is that it permits researchers to collect information that participants can report about themselves like their beliefs and motivation (Mackey \& Gass, 2005). To analyze quantitative data, descriptive statistics methods like frequency, percentage, and mean were used. On the other hand, an interview was used as the qualitative method design of this study. A qualitative method was followed to give a more objective justification on the results of quantitative method. Cohen, Manion, and Morrison (2007) said that a qualitative study design is used because the researchers are concerned with the perspectives and experiences of the teachers.

\section{Population}

For the quantitative part, 55 Iranian teachers from 5 English Institutes participated in this study and these Institutes were randomly chosen out of 10 English Institutes existing in one of the cities of Guilan, Iran. A total of 55 teachers from the 5 English institutes voluntarily participated in the quantitative dimensions of the research. These teachers took part in this study and completed the attitude questionnaire developed for the aim of this inquiry. The sample involved 40 females and 15 males with an age range of 25-35.

For the qualitative part, five volunteer participants from the five English Institutes of Iran participated in this research. They voluntarily took part in the semi-structured interview sessions of data collection processes. This study used both purposive and convenience sampling. Purposive sampling refers to the selection of individuals who can provide an understanding of the issues that are under investigation or establish a connection between research questions and sampling (Bryman, 2004; Cohen et al., 2000). For this study, the selection of EFL teachers who had teaching experience was specifically important for the researcher to investigate five teachers' attitudes towards PP2 in teaching pronunciation. Convenience sampling refers to the choice of individuals who are accessible to the researcher (Bryman, 2004). Convenience sampling involves choosing the nearest individuals to serve as respondents and continuing that process until the required sample is obtained (Cohen et al., 2000). In convenience sampling, participants voluntarily participate in a study (Creswell, 2003). For this study, willingness to participate was important because the participants were asked to spend extra time and effort for this research. The researchers talked to all 55 Iranian teachers of the 5 English institutes and chose 5 of them based on the following criteria: 1) at least 6 years of teaching experience, and (2) the use of Pronunciation Power 2 for at least 
three semesters in teaching pronunciation. Then the researchers got their agreement to participate in the qualitative aspect of this study. Therefore, these five teachers voluntarily participated in the semi-structured interview sessions of data collection processes. Before the sessions, they were given the consent forms to read and sign.

\section{Instruments}

The instrument used in quantitative study was a questionnaire which involved four components. The questionnaire called Computer Attitude Scale (CAS) and was adapted with slight modifications from Selwyn's (1997) study. There are 21 items in the CAS that measure participants' attitudes towards using PP2. The first component is called "Affect," which consists of six items and measures individual feelings towards PP2. The second component refers to "Perceived Usefulness," which consists of five items that measure individual's beliefs toward the usefulness of PP2. The third component is about "Perceived Control" and includes six items measuring the perceived easiness or difficulty of using PP2. "Behavioral Intention" is the last component which has four items measuring participants' intentions concerning PP2. The questionnaire items were measured on a five-point Likert-type scale ranging from 1 (Strongly Disagree) to 5 (Strongly Agree). A Cronbach's coefficient $a$ was calculated for each of the five scales. The $a$ coefficients for all scales were significantly high; indicating that the internal consistency of the constructs is satisfactory. The overall reliability of the scores yielded a value of $\mathrm{a}=0.90$ which reflected a high reliability of scores. Two professors were asked to judge the validity of attitude questionnaire. They were asked to judge the suitability of the items of attitude questionnaire. The researchers used professors' feedback to make the necessary modifications. These modifications were used to provide the comprehensibility of the questionnaire. Some items of questionnaire were slightly revised based on the professors' comments. The slight modifications in the attitude questionnaire were that the words Pronunciation Power 2 (PP2) and teaching pronunciation were added to all items. Questionnaire was developed in English and was not translated into Persian language because Iranian teachers had enough comprehension of questionnaire used in this research. The reliability of the adapted questionnaire was assessed using the internal consistency, Cronbach's alpha. The estimated coefficient Cronbach's alpha was 0.70 . It has been suggested that the internal reliability acoefficient values around 0.70 are "adequate" and values around 0.80 are "very good" and values around 0.90 are considered "excellent" (Kline, 2005). Therefore, it was concluded that questionnaire has sufficient reliability.

The instrument used in qualitative study was semi-structured interview questions which consisted of three questions that covered teachers' attitudes towards using PP2 in teaching pronunciation. The researchers constructed seven questions based on Iranian teachers' attitudes towards PP2. Then to ensure the validity of the semi-structured interview questions, they were sent to two professors for review. They were requested to judge the suitability of the semi-structured interview questions. Softcopies of the items were emailed to Iranian professors after getting their consent to judge the items. Feedback obtained from the professors were used to make modifications. These necessary amendments were made to provide the comprehensibility and clarity of the 
semi-structured interview questions. Through their feedback and modifications, three questions were selected for doing the objectives of this research.

\section{Data Collection}

For the quantitative part, a questionnaire was used as the research tool for data collection. The researchers explained the aims of this study to teachers. They expressed that the information gathered by this questionnaire would be used just for the objectives of this study. They distributed the questionnaire to the teachers in November, 2017 in the five English institutes in one of the cities of Guilan Province, Iran. The quantitative survey lasted for three weeks. Then the researchers collected the completed answers from all of them.

For the qualitative part, the researchers used semi-structured interview questions as the instrument of this research. Interview questions were conducted with five volunteer participants from the five institutes. They asked interviewees some questions regarding their attitudes towards PP2. They used a tape recorder for recording interviews. After finishing interviews, the researchers transcribed them using word-by-word transcription. The qualitative method lasted for five weeks.

\section{Data Analysis}

For the quantitative data, the researchers examined the completed copies of the questionnaire and used them for statistical analysis. The findings of the questionnaire were analyzed through descriptive statistics using SPSS. Descriptive statistics consisted of frequency counts, percentages, and means. The qualitative data analysis was done through examining and organizing data, coding, and identifying themes. The process of data analysis consisted of the following steps: (1) reading semi-structured interview transcripts and then organizing them into retrievable parts, (2) coding the data and classifying them into categories, (3) connecting the categories and looking for relationships between them, and (4) creating tables to indicate the categories and relationships (Holliday, 2002). The researchers used teachers' pseudonyms instead of their real names. They were called P1, P2, P3, P4, and P5. The data collected from the interview questions were analysed to find patterns of ideas emerging from them. First, the data from the interview transcriptions were read and the coding methods were applied to find any regularities or patterns of ideas from the interviewees. The researchers coded the themes originated from the interviewees' interviews. This coding system extracted codes from words or phrases that the interviewees uttered. Themes were constructed by the researchers and considered as the unit of analysis for the collected data. One Associate Professor and one Professor were asked to validate the themes. They confirmed the themes. Finally, the categories were labelled and made available for reporting as research results.

\section{FINDINGS}

The data obtained are analysed using the Statistical Package for the Social Sciences (SPSS version 16). The mean value was used to see an increment in student achievement in learning before and after the quasi experiment. T-test statistical analysis was used to 
see the differences between the two groups of students in the control and treatment group. The t-test analysis for the effects of web-based multimedia simulation application showed improvements on the overall students' performances in the pilgrimage topics tests as shown in Table 2.

\section{Quantitative Data Analysis}

The questionnaire used in this study consists of teachers' attitudes towards using PP2 in pronunciation instruction. A number of questions have been designed to assess teachers' attitudes towards PP2. The questionnaire was filled by teachers in 5 institutes. Table 1 presents the frequency and percentage of each item.

Table 1

The frequency and percentage of items in attitude questionnaire

\begin{tabular}{|c|c|c|c|c|c|c|c|}
\hline \multirow{11}{*}{ 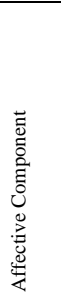 } & & Items & SD & $\mathrm{D}$ & $\mathrm{N}$ & A & SA \\
\hline & & If given the opportunity to use PP2 in teaching & $(45.45)$ & $(14.54)$ & $(18.18)$ & $(16.36)$ & $(5.45)$ \\
\hline & $\mathrm{AF} 1$ & $\begin{array}{l}\text { pronunciation, I was afraid that I might } \\
\text { damage it. }\end{array}$ & 25 & 8 & 10 & 9 & 3 \\
\hline & & I hesitate to use PP2 in teaching pronunciation & $(56.36)$ & (5.45) & (5.45) & (23.63) & (9.09) \\
\hline & AF2 & for fear of making mistakes I can't correct. & 31 & 3 & 3 & 13 & 5 \\
\hline & & I don't feel apprehensive about using PP2 in & (34.54) & $(10.90)$ & (14.54) & (34.54) & (5.45) \\
\hline & AF3 & teaching pronunciation. & 19 & 6 & 8 & 19 & 3 \\
\hline & AF4 & The use of PP2 in teaching pronunciation & $(0.0)$ & (43.63) & $(25.45)$ & (3.63) & (27.27) \\
\hline & AF4 & makes me feel uncomfortable. & 0 & 24 & 14 & 2 & 15 \\
\hline & & Using PP2 in teaching pronunciation does not & $0(0)$ & (5.45) & $(12.72)$ & (27.27) & $(54.54)$ \\
\hline & AF5 & 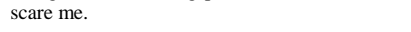 & 0 & 3 & 7 & 15 & 30 \\
\hline \multirow{11}{*}{ 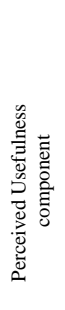 } & AF6 & I hesitate to use PP2 in teaching pronunciation & $(5.45)$ & (5.45) & (12.72) & $(41.81)$ & (34.54) \\
\hline & АГО & in case I look stupid. & 3 & 3 & 7 & 23 & 19 \\
\hline & PU1 & $\begin{array}{l}\text { The use of PP2 helps me improve my } \\
\text { pronunciation instruction. }\end{array}$ & $\begin{array}{c}(5.45) \\
3\end{array}$ & $\begin{array}{c}(23.63) \\
13\end{array}$ & $\left.\begin{array}{c}(10.90) \\
6\end{array}\right)$ & $(23.63)$ & $\begin{array}{c}(36.6) \\
20\end{array}$ \\
\hline & & PP2 makes it possible for me to teach & $(12.72)$ & (14.54) & $(7.27)$ & $(25.45)$ & (40) \\
\hline & PU2 & pronunciation more productively. & 7 & 8 & 4 & 14 & 22 \\
\hline & PU3 & PP2 allows me to find more interesting & (0) & $(9.09)$ & $(9.09)$ & $(50.90)$ & $(30.90)$ \\
\hline & PU3 & materials in teaching pronunciation. & 0 & 5 & 5 & 28 & 17 \\
\hline & PU4 & Most things that PP2 uses for teaching & (34.54) & (34.54) & $(12.72)$ & $(12.72)$ & $(5.45)$ \\
\hline & $\mathrm{PU} 4$ & pronunciation I can do just as well myself. & 19 & 19 & 7 & 7 & 3 \\
\hline & & PP2 can enhance the presentation of my work & (25.45) & $(30.90)$ & (10.90) & (18.18) & (14.54) \\
\hline & PU5 & $\begin{array}{l}\text { in teaching pronunciation that justifies the } \\
\text { extra work. }\end{array}$ & 14 & 17 & 6 & 10 & 8 \\
\hline \multirow{12}{*}{ 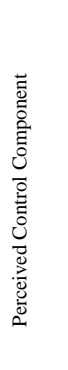 } & $\mathrm{PCl}$ & PP2 can teach most of the things I need to & (0) & (23.63) & $(5.45)$ & 10.90) & $(60.0)$ \\
\hline & PC1 & know about pronunciation. & 0 & 13 & 3 & 6 & 33 \\
\hline & & I can use PP2 for teaching pronunciation & $(54.54)$ & (18.18) & (14.54) & (12.72) & (0) \\
\hline & $\mathrm{PC} 2$ & according to my needs. & 30 & 10 & 8 & 7 & 0 \\
\hline & & If I get problems using PP2 for teaching & (14.54) & (14.54) & (0) & $(21.81)$ & $(49.09)$ \\
\hline & PC3 & $\begin{array}{l}\text { pronunciation, I know how to solve them one- } \\
\text { way or another. }\end{array}$ & 8 & 8 & 0 & 12 & 27 \\
\hline & PC4 & I am not in complete control when I use PP2 & $(58.18)$ & (14.54) & (9.09) & (9.09) & $(9.09)$ \\
\hline & $\mathrm{PC}_{4}$ & in teaching pronunciation. & 32 & 8 & 5 & 5 & 5 \\
\hline & & I need an experienced person when I use PP2 & (0) & $(5.45)$ & (12.72) & (27.27) & $(54.54)$ \\
\hline & PC5 & in teaching pronunciation. & 0 & 3 & 7 & 15 & 30 \\
\hline & PC6 & I do not need someone to tell me the best way & $(52.72)$ & $(30.90)$ & (0) & (1.36) & (0) \\
\hline & & to use PP2 in teaching pronunciation. & 29 & 17 & 0 & 9 & 0 \\
\hline \multirow{8}{*}{ 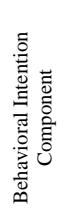 } & & I would avoid teaching pronunciation if I knew & $(52.72)$ & $(30.90)$ & (0) & $(10.90)$ & $(5.45)$ \\
\hline & Bll & it involved working with PP2. & 29 & 17 & 0 & 6 & 3 \\
\hline & & I avoid coming into contact with PP2 in & $(50.90)$ & $(25.45)$ & (9.09) & $(9.09)$ & $(5.45)$ \\
\hline & BI2 & teaching pronunciation. & 28 & 14 & 5 & 5 & 3 \\
\hline & BI3 & I only use PP2 for teaching pronunciation & $(12.72)$ & (38.18) & (14.54) & $(21.81)$ & $(12.72)$ \\
\hline & B13 & when I am told to. & 7 & 21 & 8 & 12 & 7 \\
\hline & & I will use PP2 regularly for teaching & $(5.45)$ & $(10.90)$ & (14.54) & $(30.90)$ & $(38.18)$ \\
\hline & BI4 & pronunciation throughout institute. & 3 & 6 & 8 & 17 & 21 \\
\hline
\end{tabular}


As Affective Component indicates, teachers agreed that they did not fear, were not hesitant, and were comfortable in using PP2. In addition, teachers did not have the feeling of being anxious about using the software. That is, they had complete confidence in using it for the better instruction of pronunciation. In Perceived Usefulness, teachers used PP2 as a useful way of teaching pronunciation and finding interesting pronunciation materials. Moreover, they agreed on improving the quality of their pronunciation instruction with the help of PP2. According to Perceived Control, teachers used PP2 based on their educational needs, solved their problems through this software, and were in control of PP2 while using it. Furthermore, approximately all teachers agreed that they need an experienced person to help them when having a specific problem related to PP2 and they also need someone to say them the best ways of using PP2 for teaching pronunciation. Finally, in Behavioral Intention, participants agreed that they will use PP2 for teaching pronunciation and will never avoid using it, do not use PP2 for instruction when they are told to do, and use it for teaching other courses of Institutes. The mean scores of attitude questionnaire were calculated. There were four components in this questionnaire. They were affective, perceived usefulness, perceived control, and behavioral intention components in the CAS (Selwyn, 1997). All 55 Iranian teachers answered all items and no missing data was found in the survey. The mean scores of these components are shown in Table 2.

Table 2

Mean scores in attitude questionnaire

\begin{tabular}{llll}
\hline No. & Components & No. of Items & Mean Score \\
\hline 1. & Affective & 6 & 3.93 \\
2. & Perceived Usefulness & 5 & 3.17 \\
3. & Perceived Control & 6 & 2.55 \\
4. & Behavioral Intention & 4 & 2.60 \\
\hline
\end{tabular}

All mean scores were greater than 2.0, ranging from a low of 2.55 to a high of 3.93. This shows positive responses to the components. According to the above table, the highest component belongs to Affective with the mean score of 3.93 and the lowest component belongs to Perceived Control with the mean score of 2.55. The mean score in Affective suggests that teachers were more positive about their affective component towards PP2 than their perceptions of the usefulness of the PP2, intention to use, and their control of the PP2. The findings implied that teachers perceived themselves to be in control of PP2 to a lesser degree than they thought PP2 was useful (usefulness) and had liked (affective) and intent to use (behavioral) the software. On the whole, the findings obtained from the questionnaire indicated that Iranian teachers had positive attitudes towards using PP2 in teaching pronunciation.

\section{Qualitative Data Analysis}

The researchers searched and coded repeating words to obtain specific themes that were pertinent to teachers' attitudes towards using PP2. Then, they compared all these words and classified them to generalize these themes. Four major themes emerged from the data analysis: interactive environment, self-confidence, interest, and training and computer experts. These themes were used for the presentation of semi-structured 
interview findings. The themes were separately explained and then they were supported by the interviewees' opinions. Important themes are indicated in the following table.

Table 3

Important themes in teachers' attitudes towards PP2

\begin{tabular}{ll}
\hline No. & Themes \\
\hline 1. & Interactive Environment \\
2. & Self-Confidence \\
3. & Interest \\
4. & Training \\
\hline
\end{tabular}

\section{Interactive Environment}

The findings of interviews showed teachers' positive attitudes towards using PP2 because it provided an enjoyable and interactive environment and they improved their American accent, stress, intonation, pronunciation of vowel and consonant sounds, and generally had native-like pronunciation in their speech. The findings showed that P1 changed his American accent, stress, and intonation because PP2 provided a fascinating setting for him to teach different aspects of pronunciation.

Um... as far as I know, an interesting learning and teaching environment was provided by... PP2 and through this environment I improved my, uh... American accent, stress and intonation and, I, um... taught them to my students.

The important role of a good environment in the learning and teaching of pronunciation was stressed by P2. He improved his stress, vowel sounds, and American accent because PP2 created an interactive environment for him to learn and teach the above features.

Well... when I was using PP2, I, uh... felt comfortable to be in an interactive environment and so I... learnt a lot through PP2 such as, um ... the pronunciation of some difficult vowels, correct stress on words, uh... speaking with American Accent.

Like P2, P3 also made better his vowel and consonant sounds, true stress, and American accent by means of a very good learning environment that PP2 provided for him.

Yes... PP2 provided an appropriate environment for me to learn pronunciation and so I, uh... could improve my pronunciation abilities in the fields of ... correct production of vowel sounds and consonants, correct stress on words and, uh... especially my American accent to understand native speakers of English. $\quad P 3$

A fascinating and interactive environment for teaching pronunciation was provided for P4 and he felt that PP2 had a good impact on him to learn and teach American accent, stress, intonation, speaking, and listening.

Yes... PP2 helped me to... to... improve my pronunciation abilities such as American accent, stress, intonation, speaking and, um... listening and I was happy to use PP2 because it... provided an interesting and interactive environment for me that had an effect on me to, uh... talk English to my students much better than when I was not familiar it.

PP2 contained S.T.A.I.R. exercises and these had an important effect on P5 to improve her speaking skills through too much practice in stress, intonation, and rhythm patterns. 
Ok, I think that one of the useful features within PP2 was, uh... S.T.A.I.R. exercises. These exercises helped me, um... enhance my pronunciation in the fields of correct...stress, intonation, and rhythm so that I improved my speaking abilities. P5

\section{Self-Confidence}

Interviews indicated that one of the advantages of using PP2 was that it increased teachers' self-confidence in teaching pronunciation. The findings also showed that teachers were confident about using PP2 and this means that teachers who have high confidence try to use it in teaching pronunciation more than those who have less confidence. P1 emphasized that PP2 had a good effect on him to enhance his confidence and this in turn improved his stress and accent.

When I used PP2, it...increased my self-confidence to use it as an effective technology in enhancing my, um...capability in different fields of pronunciation like, uh...correct stress and accent.

P3 stated that his confidence increased while using PP2 and he continued that it was an effective tool for motivating him to improve intonation, stress patterns, and accent.

Yes... I am completely sure that the use of PP2 increased, uh... my confidence in teaching pronunciation and, uh... it caused a high motivation in me to always use $i t$, h ... as a reliable source for improving my English pronunciation specifically, um... intonation, stress patterns and American accent.

The true use of PP2 helps teachers to teach well and decreases their stress and apprehension. P5 maintained that PP2 both increased his confidence and reduced his anxiety. These factors helped him to teach word stress and sentence stress effectively.

Right, I am very interested in using PP2 because it enhanced my, uh... selfconfidence and it also created a positive attitude in me because it decreased my, um... my fear and stress to be able to use it well in... teaching word stress and sentence stress.

Interest

Interviews showed that teachers were very interested in using PP2 because it provided numerous teaching pronunciation materials for them. The findings indicated that PP2 had a high potential for teachers and they were happy to use it in their instruction. They had much interest and strong motivation for using PP2 concerning its effect on their pronunciation. P2 stated that his interest in PP2 was due to the many activities it provided for him to change his pronunciation.

Yes... PP2 offered me individualized instruction, a lot of practice by listening discrimination, and $u h \ldots$ repetition exercises and these created $a, u h \ldots$ a high interest in me to use it to improve my English pronunciation.

Interviews indicated that PP2 had an effect on P3 to improve his instruction because it had a lot of pronunciation lessons and these aroused his interest in this software.

Well... PP2 has so many useful lessons and exercises like, um... vowel sounds, consonant sounds, listening games that, uh... that aroused my interest. I mean these materials really helped me to enhance my pronunciation instruction. $\quad P 3$ 
A similar comment was shared by $\mathrm{P} 4$. He said that PP2 offered numerous pronunciation materials for him. These materials motivated him and made better his instruction.

Ok, I have a keen interest in using PP2 because it has many, um... learning materials like stress patterns, listening games and, uh... sentences that improve my speaking skill and these materials are... necessary for me to make better my teaching.

Training

The findings revealed that teachers had two serious challenges for utilizing PP2. The first thing was training in using the software and the second one was the attendance of computer experts in the language labs. These two issues had important roles in solving teachers' technical problems in using PP2. The findings showed that when teachers are trained in PP2 and also see the computer specialists in the lab, these factors automatically increase their motivation for the more use of it in teaching pronunciation and solving the possible problems that they will face them. Interviews showed that teachers could solve their technical problems by the presence of computer experts in the language lab and training courses in the software.

Right... training is the most important factor for integrating, uh... PP2 in teaching pronunciation and because I had already a, um... short time training in it so this helped me to solve... technical problems I encountered in using PP2 in the language lab.

Ok, when I was thinking about the person who could help me when, um... facing with technical problems in PP2, this always... worried me. But after seeing the computer expert in the language lab, uh... I was very happy that the computer expert is there to ... solve the technical problems I will probably have in the future. $P 2$

Well, without teacher training in PP2, uh... I couldn't teach pronunciation efficiently. I've got my knowledge of PP2... from attending workshops. I expect attending more workshops that are, um... pertinent to the use of PP2 in teaching pronunciation.

\section{DISCUSSION}

Iranian teachers had positive attitudes towards using PP2 in teaching pronunciation. They indicated their positive attitudes towards PP2 both in questionnaire and semistructured interviews. The positive attitudes of teachers are an important factor in the use of computer technologies as Jones (2001) stated that computer technologies cannot be used in instruction when teachers' attitudes are not positive towards them. Teachers who have positive attitudes towards computer technologies can use them better than those who lack these attitudes. Computer technologies can create interactive environments for teachers that help them gain maximum ability in their teaching. These technologies offer a lot of exercises and techniques for teachers to practice and teach well. According to the previous research, participants' attitudes towards computer were positive because it provided an enjoyable and interactive environment for improving and teaching pronunciation. It was very easy to use and also provided up-to-date information about pronunciation (Bott, 2005). Furthermore, Lord (2008) indicated that participants 
who used podcasting software improved their pronunciation and it was also indicated that participants had good attitudes towards this software. The results of both attitude questionnaire and semi-structured interviews closely match the above studies.

Teachers' confidence can be increased while they are using computer technologies and this confidence creates positive attitudes towards using them in their instruction (Yushau, 2006). Some teachers are more confident than the other teachers in teaching pronunciation. This confidence is originated from their previous familiarity with computers, regular use of technologies, good attitudes towards them, and knowledge of these technologies. The findings revealed that the frequent use of computer will result in lower anxiety and more confidence in using it. Teachers can increase their confidence through using computer technologies and this in turn creates positive attitudes in teachers to use them (Wong et al., 2005; Yushau, 2006). The results of this research demonstrated that the majority of teachers feel comfortable to use PP2 in teaching pronunciation and use it according to their personal needs and preferences in pronunciation instruction. This finding is in accordance with the findings of Kersaint (2003) who said that teachers who have positive attitudes towards computer feel more comfortable and include it into their instruction.

The results of both attitude questionnaire and semi-structured interviews have been widely supported by the previous literature (Yuen \& Ma, 2001; Yushau, 2006), suggesting that teachers' computer use and knowledge are related to their confidence level. It has also been stated that one of the important factors to the successful use of computer technology is the increase of teacher's confidence. Perceived usefulness of computers influences teachers' attitudes and their confidence about computers impacts their instruction. Similarly, Lam (2000) said that teachers' confidence is very important because the lack of confidence stops teachers from using computer technology in their classes. Teachers should have much interest and enough motivation to use technologies because they provide many teaching opportunities for these teachers and these can create positive attitudes towards using these technologies (Yildirim, 2000). Some teachers are more motivated than the other teachers in using computers and are very interested in teaching pronunciation with computers. Teachers' high motivation arises from their interest to use computers, their in-depth knowledge of computers, and the satisfactory results obtained from the computers. Computers can provide a lot of pronunciation materials for teachers and these in turn may have a direct impact on them to improve their pronunciation instruction. The findings of both questionnaire items and semi-structured interviews are in line with the above study. Training in computer technologies in general and PP2 in particular can facilitate the process of teaching pronunciation. Teachers can receive their training from multiple sources including the researcher, self-taught, and college courses. It is concluded that with the appropriate training in using computers, teachers can be quite confident and motivated in the use of computers as the important tools of teaching and can enhance their students' learning. English Institutes should provide teachers with the necessary support with regards to training in computers. Teachers' training is very significant for the successful use of computers and it allows them to connect the knowledge that they learn through computers to their actual instruction (Chen, 2008; Dudeney \& Hockly, 2007). 
Previous literature supports the idea that computer technology training is one of the crucial factors that helps teachers develop positive attitudes towards computer technology and integrating it into their instruction (Reynolds \& Morgan, 2001; Yildirim, 2000). The results of attitude questionnaire and semi-structured interview questions have been supported by the previous literature (Egbert, Paulus, \& Nakamichi, 2002; Oh \& French, 2007; Yildirim, 2000). These researchers stated that as a result of training periods, teachers improved their abilities with computer technology and gained confidence that affected their attitudes toward it. In addition, Hirata (2004) stated that trained groups who utilized computer software for their pronunciation instruction had a significant improvement in words-in-sentences contexts and participants had also positive attitudes towards using computer software for teaching pronunciation. The results of this study revealed that teachers have the technical ability and basic knowledge of PP2 to solve their possible problems when teaching pronunciation and these factors helped them teach pronunciation effectively. This finding is in line with the findings of Berner (2003) and Ocak and Akdemir (2008), expressing that teachers' computer literacy is pertinent to their computer use and it has a positive effect on teachers to use it in their teaching programs. One of the important aspects of doing training courses on computer technology is that trainers should have expert knowledge in computer and pronunciation instruction. This finding is in line with Warschauer's (2002) study, indicating that teachers should be provided with computer knowledge and later trainings should be built on the previous trainings as to combine language teaching activities with computer technologies.

\section{CONCLUSION}

This study investigated Iranian English Institutes teachers' attitudes towards using Pronunciation Power 2 (PP2) in pronunciation instruction. The use of PP2 has a great potential in providing new pronunciation learning and teaching opportunities for both learners and teachers. The findings of this study indicated that teachers had positive attitudes towards utilizing PP2 and supported the use of this software in teaching pronunciation. The findings showed that in order to promote positive attitudes towards PP2 among teachers, it is important to pay attention to what teachers think about PP2 and its usefulness for their instruction, what their knowledge and skills are or what skills they need to develop. The use of computer technology in general and PP2 in particular is expected to provide teachers an interactive and interesting environment to teach pronunciation effectively. All teachers throughout the world may find the application of computer technologies useful for teaching pronunciation. The findings of the questionnaire items and semi-structured interview questions indicated the positive effect of PP2 on teachers' pronunciation instruction. Training in computer technologies facilitates the process of teaching pronunciation. With the appropriate training in computer technologies, teachers can be quite confident and motivated in using them as the important tools of teaching pronunciation and can enhance their learners' learning. It is important to incorporate teacher training courses to improve teachers' computer knowledge. 
We need more research and insights into the kinds of computer skills which are pertinent to pronunciation instruction in various contexts. Although the researchers used a small number of teachers for this study, the findings represented that the use of computer pronunciation software is regarded as a solution for overcoming the possible difficulties teachers may have in teaching pronunciation. The researchers believe that selecting suitable computer technologies will undoubtedly improve the quality of teaching pronunciation at the English Institutes levels. It can be concluded that using computer technologies in pronunciation classrooms cannot provide rapid progress in the short-term. The use of technologies in teaching pronunciation will certainly bring about successful outcomes in the long-run. Although the analysis of the questionnaire items and semi-structured interview questions indicated that teachers have confidence in using computer pronunciation software in order to improve their pronunciation instruction, it is necessary to take advantage of their trust and provide the necessary conditions in future, in which it could be possible to use different computer technologies that ultimately lead to learners' progress. It is also necessary for teachers to receive continuous training through attending workshops, seminars, and conferences in order to obtain the necessary knowledge and skills to use computer technologies for the effective teaching of pronunciation. Future research should concentrate on knowing the most appropriate applications of computer software in teaching pronunciation in different English Institutes in particular and EFL contexts in general.

\section{REFERENCES}

Aziz Mohammadi, F., \& Samadi, F. (2014). The impact of call on improving Iran students' accent. Indian Journal of Scientific Research, 7(1), 794- 798. https://www.ijsr.in/upload/1320874941Microsoft\%20Word\%20-20Paper_106.pdf

Berner, J. E. (2003). A study of factors that may influence faculty in selected schools of education in the Commonwealth of Virginia to adopt computers in the classroom (Doctoral dissertation). George Mason University. Pro Quest Digital Dissertations (UMI No. AAT 3090718).

Bo, L., \& Bo, S. (2005). Accent Master (Farsi ed.) [Computer software]: New York. Retrieved from http://www.accentmaster.com/.

Bott, A. (2005). Computer-aided self-access pronunciation materials designed to teach stress in American English (Unpublished master's thesis). Brigham Young University, Provo, Utah, United States. http://scholarsarchive.byu.edu/etd

Bryman, A. (2004). Social Research Methods. Oxford: OUP.

Cauldwell, R. (2002). Streaming Speech: Listening and pronunciation CD-ROM. Birmingham: Speech in action.

Cavas, B., \& Kesercioğlu, T. (2003). Primary science teachers' attitudes toward computer assisted learning. Ege Journal of Education, 3(2), 35-43. dergipark.ulakbim.gov.tr/egeefd/article/view/5000004065

Chen, C. (2008). Why do teachers not practice what they believe regarding technology integration? Journal of Educational Research, 102(1), 65-75. https://doi.org/10.3200/JOER.102.1.65-75 
Chen, Y. L. (2008). A mixed-method study of EFL teachers' Internet use in language instruction. Teaching and Teacher Education, 24(4), 1015-1028. https://eric.ed.gov/?id=EJ789364

Cohen, L., Manion, L., \& Morrison, K. (2000). Research methods in education (5th ed.). London: Routledge Falmer.

Cohen, L., Manion, L., \& Morrison, K. (2007). Research methods in education (6th ed.). New York, NY: Routledge. https://www.amazon.com/Research-MethodsEducation-Louis-Cohen/dp/0415368782

Creswell, J. W. (2003). Research design: Qualitative, quantitative, and mixed methods approaches (2nd ed.). Thousand Oaks, CA: Sage.

Egbert, J., Paulis, T. M., \& Nakamichi, Y. (2002). The impact of CALL instruction on classroom computer use: A foundation for rethinking technology in teacher education. Language Learning and Technology, 6(3), 108-126. http://llt.msu.edu/vol6num3/egbert/

Farhat, P. A., \& Dzakiria, H. (2017). Pronunciation barriers and computer assisted language learning (CALL): Coping the demands of $21^{\text {st }}$ century in second language learning classroom in Pakistan. International Journal of Research in English Education, 2(2), 53-62. doi: 10.18869/acadpub.ijree.2.2.53

Finley, L., \& Hartman, D. (2004). Institutional change and resistance: Teacher preparatory faculty and technology integration. Journal of Technology and Teacher Education, 12(3), 319-337. https://eric.ed.gov/?id=EJ723697

Gobbo, C., \& Girardi, M. (2001). Teachers' beliefs and integration of information and communications technology in Italian schools. Journal of Information Technology for Teacher Education, 10(1\&2), 63-86. http://dx.doi.org/10.1080/14759390100200103

Gorjian, B., Hayati, A., \& Pourkhoni, P. (2013). Using Praat software in teaching prosodic features to EFL learners. Procedia - Social and Behavioral Sciences, 84(9), 34 - 40. https://doi.org/10.1016/j.sbspro.2013.06.505

Gulbahar, Y. (2008). ICT usage in higher education: A case study on pre-service teachers and instructors. The Turkish Online Journal of Educational Technology, 7(1), 32-37. Retrieved from www.tojet.net

Haghighi, M., \& Rahimy, R. (2017). The effect of L2 minimal pairs practice on Iranian intermediate EFL learners' pronunciation accuracy. International Journal of Research in English Education, 2(1), 42-48. doi: 10.18869/acadpub.ijree.2.1.42

Hirata, Y. (2004). Computer assisted pronunciation training for native English speakers learning Japanese pitch and durational contrasts. Computer Assisted Language Learning, 17(3-4), 357-376. https://doi.org/10.1080/0958822042000319629

Holliday, A. (2002). Doing and writing qualitative research. Thousand Oaks, CA: Sage. Huang, H. M., \& Liaw, S. S. (2005). Exploring user's attitudes and intentions toward the web as a survey tool. Computers in Human Behavior, 21(5), 729-743. doi:10.1016/j.chb.2004.02.020 
Jafari, D., Dabaghi, A., \& Vahid Dastjerdi, H. (2015). The effects of integrating ICT resources into reading comprehension in Iranian high school. International Journal of Research Studies in Language Learning, 4(2), 57-68. doi: 10.5861/ijrsll.2014.851

Jenkins, J. (2004). Research in teaching pronunciation and intonation. Annual Review of Applied Linguistics, 24(1), 109-125. https://doi.org/10.1017/S0267190504000054

Jones, B. G. (2002). Emerging technologies: Technology for prospective language teachers. Language Learning and Technology, 6(3), 10-14. http://llt.msu.edu/vol6numX3/emerging

Jones, J. (2001). CALL and the responsibilities of teachers and administrators. ELT Journal, 55(4), 360-367. doi: https://doi.org/10.1093/elt/55.4.360

Kersaint, G. (2003). Technology beliefs and practices of mathematics education faculty. Journal of Technology and Teacher Education, 11(4), 549-577. Norfolk, VA: Society for Information Technology \& Teacher Education. Retrieved March 25, 2018 from https://www.learntechlib.org/p/2222/.

Kline, R. B. (2005). Principles and practice of structural equation modelling $\left(2^{\text {nd }}\right.$ ed.). London: The Guilford Press.

Laborda, J. G., \& Royo, T. M. (2007). Book review: How to teach English with technology (Gavin Dudeney \& Nicky Hockly). Educational Technology \& Society, $10(3)$, 320-324. https://pdfs.semanticscholar.org/7f12/cfc6bece0af50a708c1c943c9da4aad2bbef.pdf

Lam, Y. (2000). Technophilia vs. technophobia: A preliminary look at why second language teachers do or do not use technology in their classrooms. Canadian Modern Language Review, 56(3), 389-420. https://doi.org/10.3138/cmlr.56.3.389

Lam, Y., \& Lawerence, G. (2002). Teacher-student role redefinition during a computerbased second language project. Computer Assisted Language Learning, 15(3), 295-315. http://dx.doi.org/10.1076/call.15.3.295.8185

Likert, R. (1970). A technique for the measurement of attitudes. Reprinted in Attitude Measurement, ed. G. Summers. Rand McNally, Chicago.

Lord, G. (2008). Podcasting communities and second language pronunciation. Foreign Language Annals, 41(2), 364-379. doi: 10.1111/j.1944-9720.2008.tb03297.x

Mackey, A., \& Gass, S. M. (2005). Second language research: Methodology and design. Mahwah, NJ: Lawrence Erlbaum Associates. www.readingmatrix.com/book_reviews/haghighi/book_review.pdf

Mcalister, M., Dunn, J., \& Quinn, L. (2005). Student teachers' attitudes to and use of computers to teach mathematics in the primary classroom. Technology, Pedagogy and Education, 14(1), 77-106. http://dx.doi.org/10.1080/14759390500200194

Mehrpour, S., Alavi Shoushtari, S., \& Haghighat Nezhad Shirazi, P. (2016). Computerassisted pronunciation training: The effect of integrating accent reduction software on Iranian EFL learners' pronunciation. CALL-EJ, 17(1), 97-112. callej.org/journal/171/Mehrpour-Shoushtari-Shirazi2016.pdf 
Mollaei, F., \& Riasati, M. J. (2013). Teachers' perceptions of using technology in teaching EFL. International Journal of Applied Linguistics and English Literature, 2(1), 13-22. http://dx.doi.org/10.7575/ijalel.v.2n.1p.13.

Neri, A., Cucchiarini, C., Strik, H., \& Boves, L. (2002). The pedagogy-technology interface in computer assisted pronunciation training. Computer Assisted Language Learning, 15(5), 441-467. doi: 10.1076/call.15.5.441.13473

Ocak, M. A., \& Akdemir, O. (2008). An investigation of primary school science teachers' use of computer applications. The Turkish Online Journal of Educational Technology, 7(4), 54-60. http://www.tojet.net/articles/4315.htm.

Ong'onda, N. A., \& Muindi, M. N. (2016). Computer assisted language learning software: The effect of integrating computer assisted pronunciation training on Kenyan English phonetics class at the University level. International Journal of Academic Research in Progressive Education and Development, 5(4), 1-21. doi: 10.6007/IJARPED/v5-i4/2278 http://dx.doi.org/10.6007/IJARPED/v5-i4/2278

Oh, E., \& French, R. (2007). Pre-service teachers' perceptions of an introductory instructional technology course. CALICO Journal, 24(2), 253-267.

Pettenai, M. C., Giuli, D., \& Khaled, A. O. (2001). Information technology and staff development: Issues and problems related to new skills and competence acquisition. Journal of Technology and Teacher Education, 9(2), 153-169. https://eric.ed.gov/?id=EJ637536

Pirasteh, P. (2014). The effectiveness of computer-assisted language learning (CALL) on learning grammar by Iranian EFL learners. Procedia-Social and Behavioral Sciences, 98, 1422 -1427. https://doi.org/10.1016/j.sbspro.2014.03.561

Pokrivčáková, S. et al. (2015). CALL and foreign language education: e-textbook for foreign language teachers. Nitra: Constantine the Philosopher University. $110 \mathrm{p}$.

Pourhosein Gilakjani, A., \& Sabouri, N. B. (2014). Role of Iranian EFL teachers about using Pronunciation Power software in the instruction of English pronunciation. English Language Teaching, 7(1), 139-148. doi:10.5539/elt.v7n1p139 http://dx.doi.org/10.5539/elt.v7n1p139

Pronunciation Power. (2000). English Computerized Learning Inc., Edmonton. Publication Inc.

Protea Textware. (2007). Connected Speech. Retrieved from http://www.proteatextware.com.au/shopexd.asp?id=103\&bc=yes?id=103

Raux, A., \& Kawahara, T. (2002). Automatic intelligibility assessment and diagnosis of critical pronunciation errors for computer-assisted pronunciation learning, ICSLP, 737740. citeseerx.ist.psu.edu/viewdoc/summary? doi=10.1.1.5.1322

Reynolds, C., \& Morgan, B. (2001). Teachers' perceptions of technology in-service: A case study. In J. Price, D. Willis, N. Davis \& J. Willis (Eds.), Proceedings of SITE 2001--Society for Information Technology \& Teacher Education International Conference (pp. 982-986). Norfolk, VA: Association for the Advancement of Computing in Education (AACE). Retrieved March 25, 2018 from https://www.learntechlib.org/p/16853/. 
Rohaan, E. J., Taconis, R., \& Jochems, W. M. G. (2010). Reviewing the relations between teachers' knowledge and pupils' attitude in the field of primary technology education. International Journal of Technology and Design Education, 20(1), 15-26. doi:10.1007/s10798-008-9055-7

Sadeghi, M., \& Mashhadi Heidar, D. (2016). The effect of using phonetic websites on Iranian EFL learners' word level pronunciation. International Journal of Research in English Education, 1(1), 31-37. http://ijreeonline.com/article-1-26-en.html

Sadeghi, B., Rahmany, R., \& Doosti, E. (2014). L2 teachers' reasons and perceptions for using or not using computer mediated communication tools in their classroom. Journal of Language Teaching and Research, 5(3), 663-673. doi:10.4304/jltr.5.3.663673.

Selwyn, N. (1997). Students' attitudes toward computers: Validation of a computer attitude scale for 16-19 education. Computers and Education, 28(1), 35-41. https://doi.org/10.1016/S0360-1315(96)00035-8

Stibbard, R. (1996). Teaching English intonation with a visual display of fundamental frequency. The Internet TESL Journal, 2(8). http://iteslj.org/Articles/Stibbard-Intonation.

Tahriri, A., Azim Dokht, Z., \& Derakhshan, O. (2013). An investigation into EFL instructors' attitudes towards using instructional technology in language classes: A case study. Research Journal of Applied Sciences, Engineering and Technology, 5(14), 3741-3750. maxwellsci.com/print/rjaset/v5-3741-3750.pdf

Teo, T. (2006). Attitudes toward computers: A study of post-secondary students in Singapore. Interactive Learning Environments, 14(1), 17-24. http://dx.doi.org/10.1080/10494820600616406

Warschauer, M. (2002). A developmental perspective on technology in language education. TESOL Quarterly, 36(3), 453-475. http://www.jstor.org/stable/3588421

Wong, S. L., Ng, S. F., Nawawi, M., \& Tang, S. H. (2005). Experienced and inexperienced Internet users among pre-service teachers: their use and attitudes toward the Internet. Journal of Educational Technology and Society, 8(1), 90-103. URL: http://www.jstor.org/stable/jeductechsoci.8.1.90

Yildirim, S. (2000). Effects of an educational computing course on pre-service and inservice teachers: A discussion and analysis of attitudes and use. Journal of Research on $\begin{array}{llll}\text { Computing in } & \text { Education, } & \text { 479-495. }\end{array}$ http://dx.doi.org/10.1080/08886504.2000.10782293

Yuen, H. K., \& Ma, W. K. (2001). Teachers' computer attitudes: factors influencing the instructional use of computers. Proceedings of the International Conference on Computers in Education (ICCE), Seoul Korea. 12-15 November 2001.

Yushau, B. (2006). Computer attitude, use, experience, software familiarity and perceived pedagogical usefulness: The case of mathematics professors. Eurasia Journal of Mathematics, Science and Technology Education, 2(3), 1-17. doi: 10.12973/eurasia.2006.00020a 